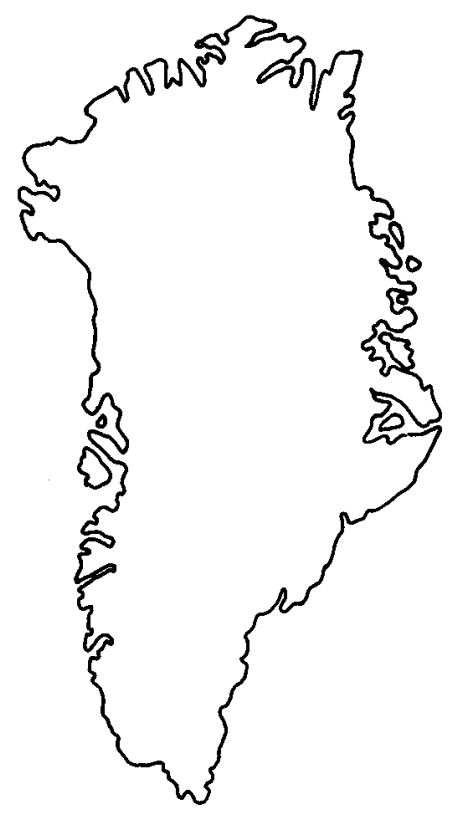

\title{
Caledonian and pre-Caledonian geology of Dronning Louise Land, North-East Greenland
}

\author{
J. D. Friderichsen, R. E. Holdsworth, \\ H. F. Jepsen and R. A. Strachan
}

The western border of the East Greenland Caledonides is exposed in Dronning Louise Land, where it is marked by a N-S trending thrust Imbricate Zone. The autochthonous crystalline basement to the west of the Imbricate Zone is dominated by orthogneisses, and unconformably overlain by two metasedimentary sequences (Zebra Series and Trekant Series). These metasedimentary units can be recognised in the Caledonian thrust slices of the Imbricate Zone and also as folded inliers in the gneiss complexes to the east, and witness to a progressive increase in Caledonian deformation and metamorphism.

J. D. F. \& H. F. J., Geological Survey of Greenland, Øster Voldgade 10, DK-1350 Copenhagen $K$, Denmark.

R. E. H., Department of Geological Sciences, University of Durham, Durham DH1 $3 L E$, England.

R. A. S., Department of Geology, Oxford Polytechnic, Oxford, OXON, OX3 OBP, England.

Dronning Louise Land is a region of mountainous nunataks extending from latitude $75^{\circ} 50^{\prime}$ to $77^{\circ} 25^{\prime} \mathrm{N}$ in North-East Greenland (fig. 1). This area is of particular interest since it is one of the few places where it is possible to examine the marginal thrust zone which defines the western limit of the East Greenland Caledonides. Current understanding of the geology of Dronning Louise Land largely derives from the work of Peacock $(1956 a, b, 1958)$ who presented petrographic and limited structural evidence for the existence of an eastdipping thrust zone subdividing the area into a western group of orthogneisses and an eastern group of paraschists and paragneisses. He demonstrated that the western gneisses were overlain unconformably by two sedimentary sequences, Trekant Series and Zebra Series, which are themselves separated in northern Dronning Louise Land by an angular unconformity. A sequence of meta-quartzites and meta-limestones, which Peacock termed the Britannia S $\varnothing$ Group, was thought to overlie the thrust zone but underlie the eastern schists and gneisses. The Britannia Sø Group was correlated with the Zebra Series, and the eastern schists and gneisses were thus regarded as the youngest sequence of rocks.

A complex polyorogenic history was inferred by Haller $(1956,1970,1971)$ who identified, on the basis of aerial photographic study and limited ground control, a series of N-S trending thrusts and two major sets of fold structures. He distinguished an older set of NW-trending folds thought to predate the Zebra Series and to have formed during a mid- to upper Proterozoic 'Carolinidian' orogeny, and a younger set of NE-trending folds and thrusts assigned to the Caledonian orogeny.

The remapping of Dronning Louise Land in 1989 reported on here has provided new information concerning the extent, age and affinities of the various sedimentary units, and a coherent structural framework for the Caledonian and pre-Caledonian evolution of the region. The geology is best described with reference to three main tectonostratigraphic units which are informally referred to as the Western Foreland, the Imbricate Zone and the Eastern Hinterland.

\section{Western Foreland}

The Western Foreland comprises a basement complex dominated by orthogneisses which is overlain unconformably by the Trekant Series and the Zebra Series. Both the gneisses and the Trekant Series are intruded by a suite of dolerites. At Prins Axel Nunatak and Zebra Klippe in northern Dronning Louise Land (fig. 1), sediments of the Zebra Series rest with marked unconform- 


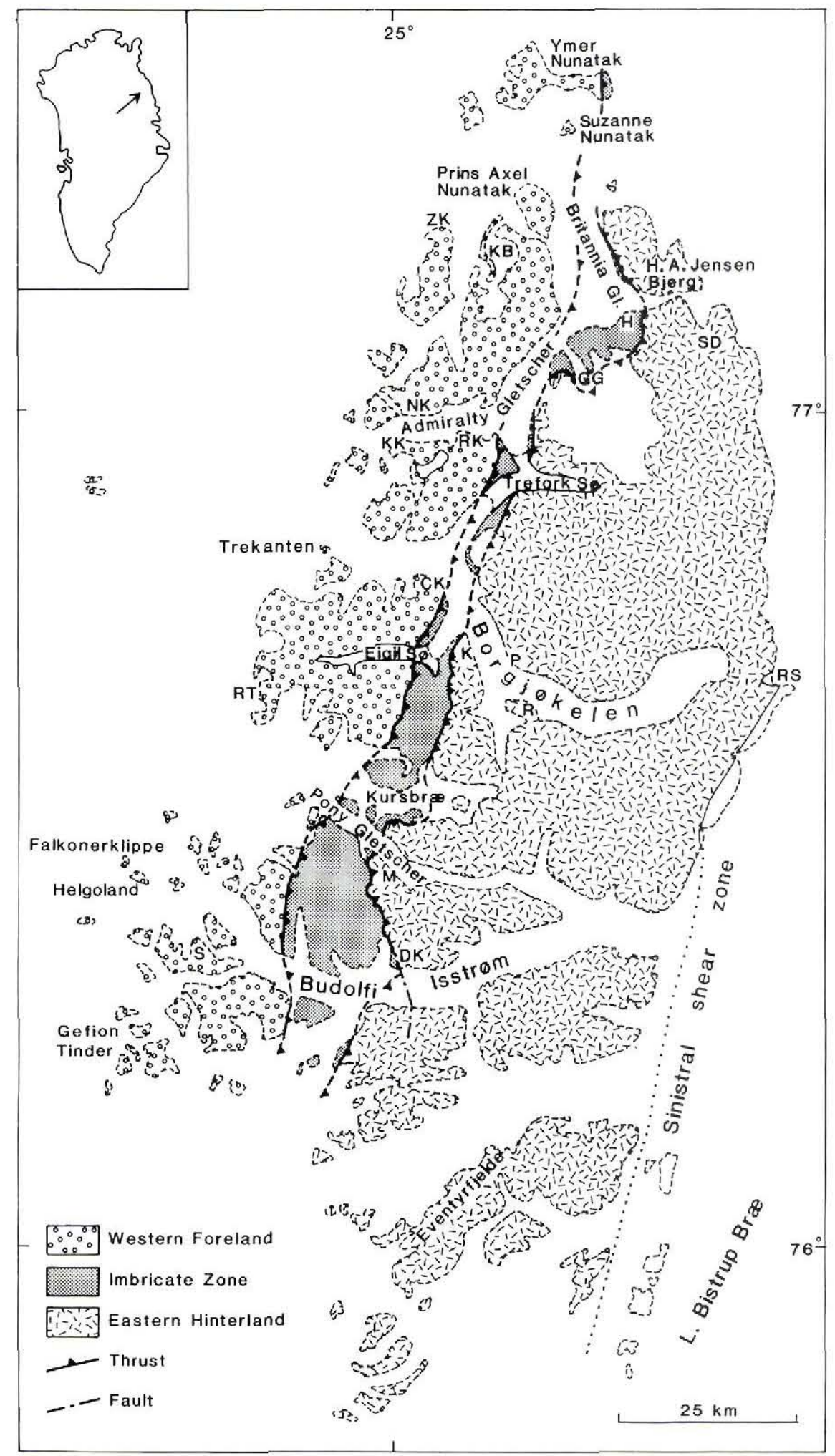

Fig. 1. Geological sketch map of Dronning Louise Land. CK, Cloos Klippe; DK, Durham Klippe; GG, Gultop Gletscher; H, Hvalryggen; KK, Kelvin Klippe; K, Kilen; KB, Krebs Bjerg; M, Monumentet; NK, Newton Klippe; P, Paradisklippe; RS, Randsøen; RK, Regnbue Klippe; RT, Revaltoppe; R, Rosmule; S, Savryggen; SD, Stranddal; ZK, Zebra Klippe. 
ity on the basement gneisses, the Trekant Series and the dolerites. Rocks of the Western Foreland become strongly folded as they are traced eastwards towards the Imbricate Zone (the thrust zone), but the region is characterised by essentially autochthonous basementcover relationships.

\section{Basement gneiss complex}

The rocks of this complex are the most important of the Western Foreland and are generally thought to represent parts of the autochthonous late Archaean - early Proterozoic North-East Greenland craton (Henriksen \& Higgins, 1976). They are well exposed along Budolfi Isstrøm, Gefion Tinder and Admiralty Gletscher where the dominant rock types are pale grey-to-pink, coarsegrained, granitic to granodioritic orthogneisses. A variably developed gneissic fabric is often present subparallel to crudely defined compositional layering, whilst ramifying networks of granitic, aplitic and pegmatitic veins are abundant. Concordant sheets of amphibolite and metasediment are locally common; metasediments present include garnetiferous schists, pyritemagnetite schists, calc-silicates, psammites and thin units of marble. These may be up to $100 \mathrm{~m}$ thick and can be traced laterally for several kilometres. Some are veined by the orthogneisses and appear to represent enclaves of the original country rock, whilst others are not veined and may be younger than the orthogneisses. Deformational intensity is variable and weakest in the western part of the region where the coarse, foliated orthogneisses of Savryggen and Eigil $\$ \emptyset$ appear to represent almost undeformed meta-igneous complexes.

\section{Trekant Series}

The Trekant Series is a sequence of sandstones and siltstones with conglomerates which unconformably overlie the basement gneiss complex (fig. 2). It has commonly been correlated with the present Independence Fjord Group of North Greenland (Peacock, 1956a; Collinson, 1980). The Trekant Series is well exposed in the region between Trekanten and Prins Axel Nunatak and sporadically in the region of Helgoland and Falkonerklippe (fig. 1). The unconformity at the base of the sequence varies from a gently undulating planar surface (e.g. Helgoland) to an irregular surface with a relief of up to $15 \mathrm{~m}$ (e.g. Zebra Klippe). The basal parts of the sequence are crudely stratified conglomerates composed mainly of angular fragments of gneiss, which pass upwards into cross-bedded, grey-green and purple-red arkosic and quartzitic sandstones with interbedded siltstones and quartz pebble conglomerates. Dessication cracks and ripple marks are commonly preserved on siltstone tops to sandstone beds. The overall sedimentary facies is consistent with a fluvial environment of deposition.

\section{Dolerites}

The basement gneiss complex and the Trekant Series are intruded by a suite of dolerites, which are so numerous in some areas as to form up to $50 \%$ of total outcrop. They vary in thickness from a few metres to over $100 \mathrm{~m}$ and are locally composite. Dolerites within the Trekant Series often appear to have been intruded at a low angle to bedding, and prior to Caledonian folding were there-
Fig. 2. Folded unconformity between basement gneiss of the Western Foreland to the lower right and centre, Trekant Series conglomerates and sandstones to the left and above. Note that a cliff ridge causes the apparent down step of the unconformity. Cliff at Newton Klippe $100 \mathrm{~m}$ high.

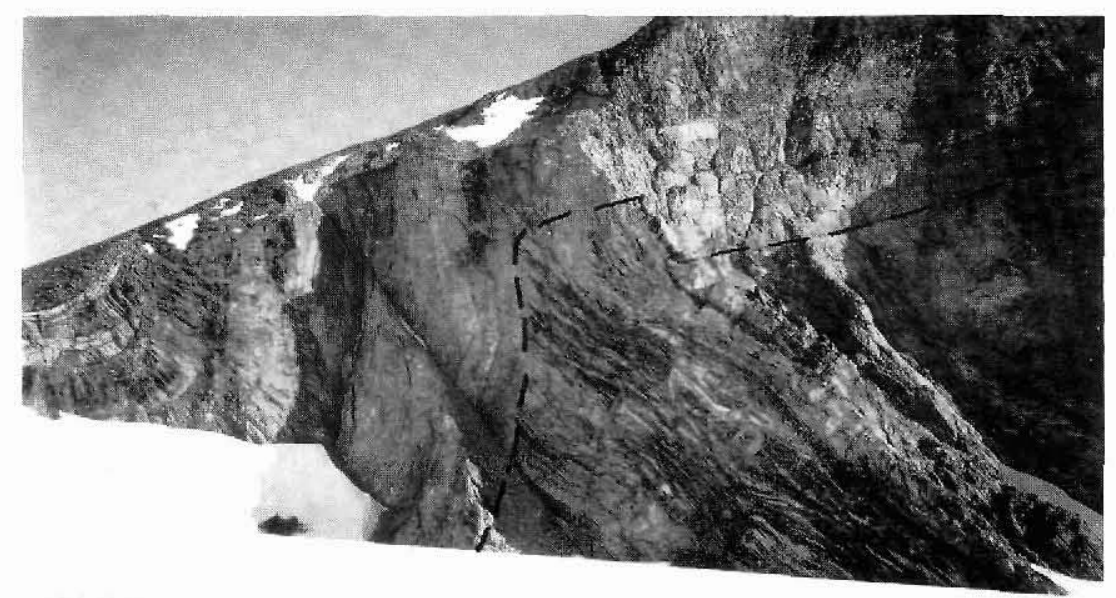


fore subhorizontal or gently dipping sills, whereas those within the basement gneiss complex form ramifying stockworks with no preferred orientation. The dolerites have been correlated with similar intrusions which are emplaced into the present Independence Fjord Group in North Greenland (Haller, 1971). If this correlation is correct, then the Rb-Sr whole-rock isochron ages of $c$. $1250 \mathrm{Ma}$ which have been obtained from the North Greenland dolerites (Jepsen \& Kalsbeek, 1979) provide a minimum age for the deposition of the Trekant Series.

\section{Zebra Series}

The Zebra Series is a thin sequence of quartzites, mudstones, magnetite sandstones and limestones which unconformably overlie the basement complex and the Trekant Series. At Zebra Klippe, Prins Axel Nunatak, Kelvin Klippe and in the region south-west of Krebs Bjerg (fig. 1), the Trekant Series and the Zebra Series are separated by an angular discordance of 5-20 (fig. $3)$; the field relationships here indicate that the Trekant Series had a gentle western dip prior to deposition of the Zebra Series. Further south, however, at Helgoland

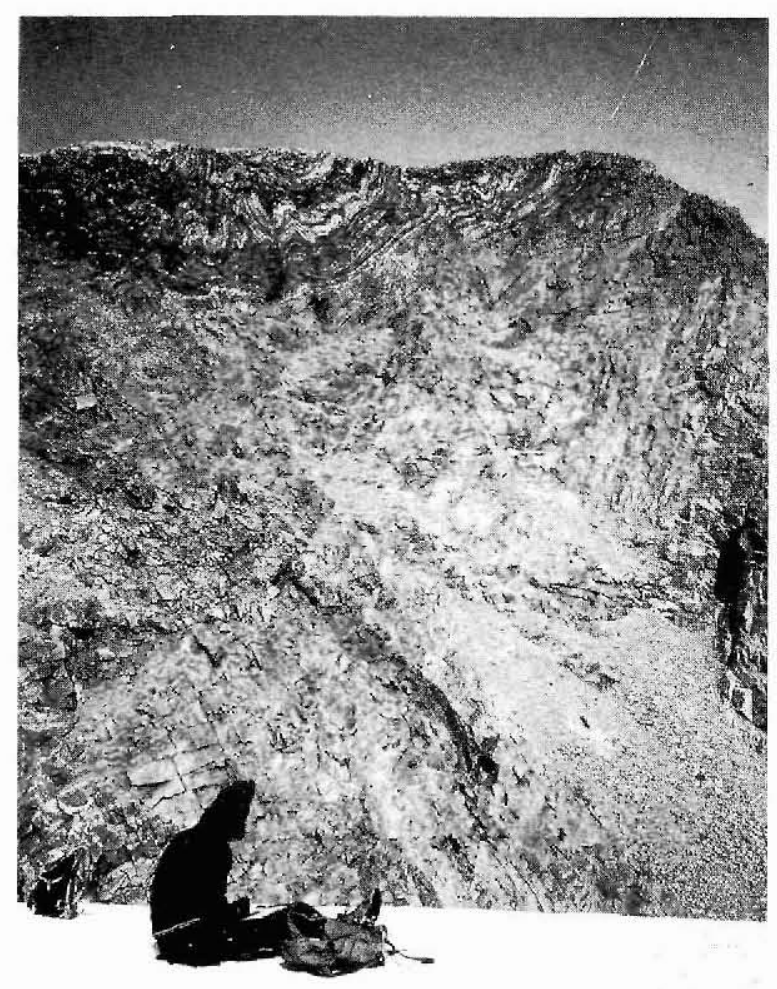

Fig. 3. Disharmonically folded Zebra Series quartzites and sandstones resting with angular unconformity on Trekant Series sandstones. Cliff $120 \mathrm{~m}$ high on south Prins Axel Nunatak. and Falkonerklippe, the boundary between the two sequences is apparently concordant (Peacock, 1956a).

The Zebra Series is not intruded by dolerites. At Zebra Klippe, Kelvin Klippe and south-west of Krebs Bjerg dolerite sheets which cut discordantly through the Trekant Series terminate abruptly at the lower boundary of the Zebra Series, demonstrating that intrusion of the dolerites pre-dated deposition of the Zebra Series.

In the region north of Admiralty Gletscher (fig. 1) the Zebra Series comprises five main lithologic units, the dominating characteristics of which are:

1. Basal pebble conglomerates and striped greenblack gritty sandstones with thin siltstone layers (c. 3-10 m).

2. Purple-white striped quartzites (c. 10-15 m).

3. Yellow-white, medium- to coarse-grained quartzites with thin mudstone layers (c. 5-30 m).

4. Interbanded magnetite sandstones, siltstones and mudstones (c. $10 \mathrm{~m})$.

5. Fine-grained, grey-black dolomitic limestones ( $c$. $10 \mathrm{~m})$.

Nowhere is the complete sequence exposed; unit 4 has only been observed in situ on Prins Axel Nunatak and unit 5 only on Suzanne Nunatak. A locality within unit 3 south-west of Krebs Bjerg contains Skolithos trace fossils. These are the only recorded fossils found in situ in Dronning Louise Land. Skolithos has long been known in glacially transported quartzite erratics in North-East and East Greenland (Haller, 1971, fig. 48) and it is possible that they originated from outcrops of the Zebra Series hidden beneath the Inland Ice. Their in situ occurrence means that the Zebra Series can be no older than the upper Proterozoic; a general correlation with similar Skolithos-bearing sediments of upper Proterozoic - early Cambrian age in Kronprins Christian Land (Hurst et al., 1985) seems likely.

\section{Imbricate Zone}

The Imbricate Zone is characterised by numerous east-dipping thrust slices within a NNE-SSW trending belt up to $15 \mathrm{~km}$ wide. The zone has been traced for 150 $\mathrm{km}$ between south-west of Budolfi Isstrøm and Ymer Nunatak (fig. 1). Individual ductile thrust sheets vary from a few metres to up to several hundred metres thickness. A single thrust sheet may be composed of up to three distinct components: basement gneisses, metasedimentary cover rocks and metadolerites. The cover rocks are thought to correspond to the Trekant Series and the Zebra Series, and include the Britannia Sø Group of Peacock (1956a,b, 1958); the latter is composite in origin, incorporating units of both the Trekant 
Series and the Zebra Series. Since the basement gneisses lack readily definable marker horizons the recognition of thrusts in areas where no cover is present is almost impossible and basement-basement thrusts have only been recognised with confidence at Gultop Gletscher and west Borgjøkelen (fig. 1).

\section{Basement gneisses}

The basement gneisses within the Imbricate Zone are similar in most respects to those found in the Western Foreland and Eastern Hinterland, except that they have often undergone intense ductile reworking during thrust-related deformation. In the higher parts of the Imbricate Zone the basement sheets are pervasively mylonitised forming thick, deceptively simple, sequences of banded schists, often with numerous pink feldspar augen. In the field there is little sign of retrogressive mineral assemblages, and deformation synchronous with thrusting appears to have occurred under amphibolite facies grade metamorphism. In the western, lowest parts of the Imbricate Zone, however, metamorphic grade decreases, and retrogressive assemblages are increasingly prominent forming grey-green phyllonitic mylonites with muscovite, chlorite, actinolite-tremolite and epidote.

\section{Metasedimentary cover rocks}

These are mostly right-way-up sedimentary sequences of low-to-medium metamorphic grade which always stratigraphically overlie basement units within individual thrust sheets. Unbroken sequences up to 200 $\mathrm{m}$ in thickness occur, but many thrust slices only preserve a few metres of sediment. Two lithologically distinct cover sequences are recognised:

(A) Pale grey-green sandstones, often with thin magnetite seams form a sequence up to 50 thick. In the region between south Britannia Gletscher and $\mathbf{H}$. A. Jensen Bjerg (fig. 1) these cover rocks are intruded by metadolerites. A distinctive horizon of conglomerate, which incorporates clasts of vein quartz, basement gneiss, pegmatite and granite, occurs at the base of the sequence. This cover sequence closely resembles the more deformed parts of the Trekant Series in the Western Foreland, a similarity reinforced by the occurrence of metadolerites in both units; a tentative correlation is proposed.

(B) Clastic sediments with limestones, which form sequences up to $c .215 \mathrm{~m}$ thick. It is significant that metadolerites are not found in this sequence, and in some areas (e.g. Kilen, Hvalryggen) metadolerites are apparently overlain unconformably by the sediments.
The limestone-bearing sequences always stratigraphically overlie the grey-green sandstone sequences with metadolerites. The thickest, and most complete, stratigraphic section observed occurs some $5 \mathrm{~km}$ south-east of Eigil $\$ \varnothing$, and comprises four main units:

1. Pale green sandstones, with thin lensoid pebble horizons up to $20 \mathrm{~cm}$ thick (c. $2 \mathrm{~m}$ ).

2 . White-to-rusty weathering, medium-grained quartzose sandstones displaying abundant tabular cross-bedding (c. $45 \mathrm{~m})$.

3. Interbanded grey-green siltstone, dark mudstone, thin quartzites, yellow sandstones and limestones and a basal unit $(1 \mathrm{~m})$ of magnetite sandstone $(c .50 \mathrm{~m})$. The base of sandstones of unit 3 preserve several well-developed trace fossils.

4. Fine-grained grey dolomitic limestone $(c .120 \mathrm{~m})$.

Similar cover successions are observed elsewhere within the Imbricate Zone, although the limestone horizon is only known from Eigil Sø and south Britannia Gletscher. The close similarity between this sequence and the Zebra Series of the Western Foreland suggests direct correlation; both lack dolerites, and unconformably overlie sequences containing dolerites.

The 1989 mapping shows that the outcrops included by Peacock $(1956 a, b)$ in his Britannia $\$ \varnothing$ Group include rocks now correlated with both the Zebra Series and Trekant Series. Peacock had suggested a correlation with the Zebra Series. The Britannia $\varnothing \varnothing$ Group is therefore abandoned.

\section{Eastern Hinterland}

The rocks forming the Eastern Hinterland can be divided into two assemblages: high-grade, migmatitic basement gneiss complexes and medium-grade, nonmigmatitic cover sequences.

\section{Basement gneiss complexes}

The basement complexes form the greater part of the Eastern Hinterland and are well exposed along Budolfi Isstrøm, Paradisklippe, eastern Trefork Sø and Stranddal (fig. 1). Intense Caledonian deformation has often obliterated early structures and fabrics, forming in many areas uniform, regularly banded gneisses. Three distinct lithologies are recognised.

(A) Acid-to-intermediate grey orthogneisses form the main rock type of the Eastern Hinterland; mafic orthogneisses are less common. Locally, polyphase intrusion histories are recognised and in general the more leucocratic members form the later intrusive units.

(B) Paragneiss sequences, including banded amphi- 
bolites, pelitic to semi-pelitic metasediments, calc-silicate skarn rocks and marbles occur in many areas. In regions of low tectonic strain (e.g. east Eventyrfjelde, Budolfi Isstrøm) these rock types can be seen to occur as enclaves within the orthogneisses, and thus probably represent the oldest rocks in the region.

(C) Pegmatites, granite veins and segregations are widespread within the orthogneisses and paragneisses and appear to be a product of the regional phase of migmatisation and high-grade metamorphism responsible for the formation of the gneissic fabrics.

The basement gneiss complexes are intruded by metabasic sheets ranging in thickness from a few millimetres to several tens of metres. These intrusions are unmigmatised, and even in zones of high tectonic strain display discordant contacts with the gneisses. In areas of low strain (e.g. Rosmule, Stranddal) they form anastomosing networks of discordant amphibolite sheets which cross-cut the gneissic foliation at high angles.

In areas less affected by Caledonian deformation, the basement gneisses closely resemble those of the Western Foreland and a tentative correlation is proposed. A corollary of this is that the metabasic intrusions of the Eastern Hinterland may represent the heterogeneously reworked equivalents of the dolerites of the Western Foreland.

\section{Cover sequences}

The cover sequences have a para-autochthonous setting and are generally preserved in the cores of early Caledonian isoclinal synclines. They are regarded as cover principally because they are not intruded by orthogneiss phases, and although they have undergone medium-grade regional metamorphism synchronous with the deformation, they are not migmatised. Two distinct types of cover sequences are recognised.

(1) Psammitic to semi-pelitic grey schists, rustyweathering, cross-bedded quartzites and minor marbles and calc-silicates, which are well exposed at Eventyrfjelde, north Budolfi Isstrøm and Borgjøkelen. This assemblage includes subconcordant metabasic intrusions, thought to be equivalent to those which intrude the basement gneisses. The sequence was therefore probably deposited on the basement gneisses prior to emplacement of the metabasic intrusions.

(2) A well-defined succession comprising in stratigraphic order: white-to-rusty, cross-bedded orthoquartzites, interbanded phyllites, psammites, quartzites and minor carbonates, and either magnetite sandstones or grey limestones. Thin basal conglomerates locally underlie the lowermost quartzites. This assemblage is best exposed at Pony Gletscher (Monumentet) and Kurs- bræ. Metabasic intrusions are entirely absent. The stratigraphic succession displayed by this assemblage is closely comparable to parts of the Zebra Series in the Western Foreland, and a correlation is proposed; this provides an important stratigraphic link across the region.

\section{Structure and metamorphism}

In all three tectonostratigraphic units the structures may be divided into pre-Caledonian and Caledonian phases. Structures which deform the Zebra Series and its correlatives (considered to be of late Precambrian early Cambrian age) are assumed to be Caledonian, and earlier structures not affecting these cover sequences are assumed to be pre-Caledonian.

\section{Pre-Caledonian structures}

Gneissic fabrics and related minor isoclinal folds are present within the basement gneiss complexes of all three tectonic units and pre-date deposition of the Trekant Series and intrusion of the dolerites. There is no clear field evidence for any major folds related to this phase.

Steep NNE-SSW trending extensional shear zones and fabrics have been identified within the basement gneiss complexes of the Western Foreland and the Imbricate Zone. They show a consistent downthrow to the ESE and they cut, and are cut by, dolerites; this may indicate synchroneity of extensional shearing and dolerite intrusion. The same phase of extension may be responsible for the angular unconformity and overstep relationships of the Zebra Series in the Western Foreland.

\section{Caledonian structures}

Caledonian structures differ in their manner of development in the three tectonostratigraphic units recognised in the region, and are discussed separately below. Since we believe that the Caledonian structures developed as a foreland propagating sequence, the earliest structures are those found in the Eastern Hinterland, and are described first.

The Eastern Hinterland. This represents the structurally most complex part of the region. Two phases of folding and associated fabrics are recognised on all scales.

A primary phase of isoclinal sheath folds is associated with a prominent $\mathrm{N}-\mathrm{S}$ mineral extension lineation. Major interfolding of basement and cover occurred during this event. Sheath fold geometries are inferred on all 


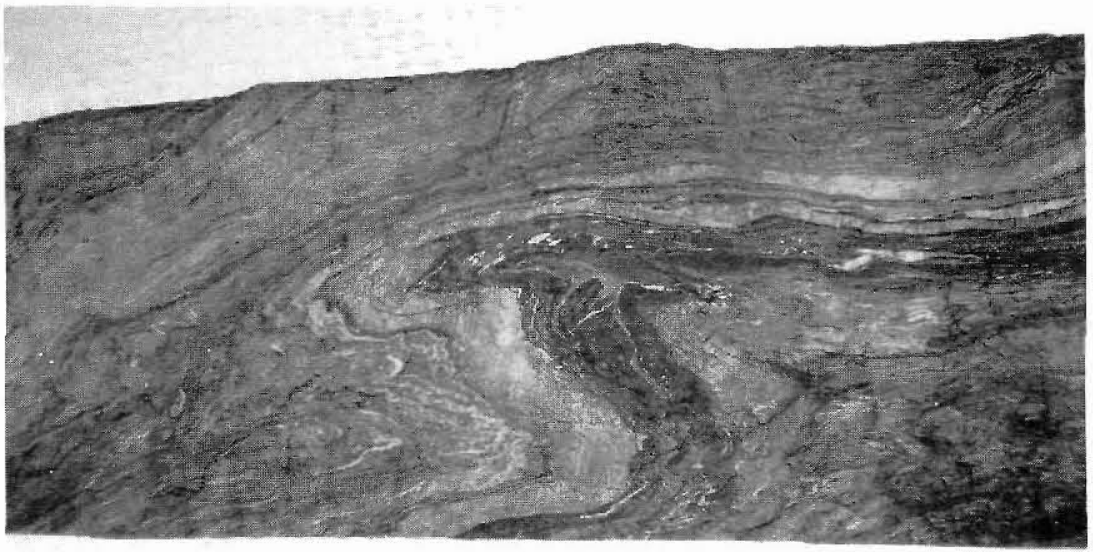

Fig. 4. SE-plunging main phase fold deforming basement gneisses of the Eastern Hinterland, adjacent to the Imbricate Zone. $300 \mathrm{~m}$ cliff facing north in central Budolfi Isstrøm.

scales, based on the widespread preservation of early 'eye' structures and bimodal facing directions within the synclinal cover infolds (cf. Holdsworth, 1988). Along the south-east margin of the region, primary structures are transposed into a major NNE-SSW trending shear zone comprising intensely mylonitised gneisses. A subhorizontal mineral lineation is widespread, and abundant shear criteria (e.g. rotated porphyroclasts, shear bands) indicate a sinistral sense of displacement. Although outcrops of this shear zone are only recognised in the area south of Randsøen and on small nunataks in L. Bistrup Bræ (fig. 1), it is thought to occupy much of the $15 \mathrm{~km}$ wide glacier region which separates Dronning Louise Land from Dove Bugt to the east.

The major structures characterising the Eastern Hinterland are generally $\mathrm{N}-\mathrm{S}$ trending, open to isoclinal folds and associated crenulation fabrics. Refolding of all earlier structures is widely recognised. A progressive change is observed from steeply-inclined fold axial surfaces in the eastern parts of the region, to westerly overturned folds as the Imbricate Zone is approached (figs 4 \& 5). In detail, minor folds display complex sheath fold patterns which result in local vergence reversals. Along the south-eastern margin of the region, minor folds of this generation deform the mylonitic fabrics related to the NNE-SSW trending sinistral shear zone (fig. 1). Minor main phase folds appear to have formed synchronously with the later stages of ductile shearing since they are curvilinear about a subhorizontal direction parallel to the stretching lineation in the shear zone. NNE-SSW trending zones of cataclasite and brittle faulting are localised within the region of the shear zone and may indicate a long-lived history of episodic reactivation. Variably cataclased granites form the south-easternmost nunataks (fig. 1), and are inferred to have been emplaced during late-stage move- ments along the shear zone. These granites may be the northernmost Caledonian granites in East Greenland.

The Imbricate Zone lies structurally below the Eastern Hinterland and represents a zone of numerous ESEdipping ductile thrusts in which variably deformed basement gneisses and cover sequences are interleaved (fig. 5). Mylonitic fabrics and associated mostly isoclinal sheath folds form the earliest group of Caledonian structures. A SE-plunging mineral extension lineation is taken to represent the direction of thrusting, and rotated porphyroclasts and shear bands within the mylonites consistently indicate top-to-the-NW senses of thrusting. These structures are refolded by folds with $\mathrm{N}-\mathrm{S}$ trending axial surfaces and south to south-east plunges, which can be correlated directly with the main phase folds of the Eastern Hinterland. A linked system of thrusts with distinct culmination zones is recognised, resulting in locally variable strike directions and widths of the Imbricate Zone. Intense ductile shearing during thrusting has resulted in low-angle thrust ramps of only a few degrees and thus most of the highly deformed cover sequences rarely exceed a few tens of metres in thickness. The majority of the imbricates now dip ESE at angles of $40-60^{\circ}$, which may indicate a late phase of back-steepening.

The Western Foreland is deformed by a single phase of NW-verging folds with associated minor thrusts. The folds are principally distinguished by their deformation of the Trekant Series and the Zebra Series, and they can be seen to decrease in intensity north-westwards away from the Imbricate Zone. In the folded cover rocks a penetrative axial-planar cleavage is developed, dipping moderately to steeply to the south-east and containing a south to south-east plunging mineral extension lineation.

Discussion. Caledonian metamorphism decreases in 
Fig. 5. Structural section along Budolfi Isstrøm showing the major Calcdonian structures of the Eastern Hinterland and the lmbricate Zone. Cover sequences (undifferentiated) are ornamented.

grade from east to west (Peacock, 1956a,b, 1958). Field observations suggest an amphibolite facies grade of metamorphism broadly synchronous with both phases of Caledonian folding in the Eastern Hinterland. In the Imbricate Zone it appears that the structurally highest thrusts formed under amphibolite facies conditions, whilst the lowest formed at low to middle greenschist facies. This apparent metamorphic inversion is most reasonably interpreted as indicating that the structures formed as a foreland propagating sequence.

A number of observations suggest that sinistral transpression is the dominant mode of Caledonian deformation in Dronning Louise Land:

(1) The prescnce of a major sinistral strike-slip shear zone along the eastern margin of the Eastern Hinterland in which the deformation is partly synchronous with the formation of both primary and main phase folds.

(2) The main phase folds appear to be the products of a complex interaction betwecn strike-slip shearing and thrusting. In regions adjacent to the Imbricate Zone the fold axes are commonly rotated towards the azimuth of thrust transport (SE). Moving eastwards the pattern of curvilinearity apparently changes so that adjacent to and within the shear zone their hinges become curvilinear through the vertical and about a NNE-SSW subhorizontal direction parallel to the mineral lineation in the shear zonc.

(3) The Caledonian structures which pre-date the main phase folds display a progressive change in the direction of tectonic transport with time from NNESSW sinistral shear to north-west directed thrusting. It is also significant that the north-westwards directed thrusting within the Imbricate Zone is markedly oblique to the regional strike.

\section{Conclusions}

- A coherent tectonostratigraphic framework is defined within Dronning Louise Land, comprising three tectonic zones, each with distinctive basement-cover relationships. It is possible to establish clear lithostratigraphic links between the cover sequences exposed within each zone. In addition an important suite of basic intrusions is present in all three zones.

- The discovery of in situ trace fossils within quartz- 
ites of the Zebra Series means that these rocks can be no older than the upper Proterozoic. By implication the structures which deform these rocks and their probable correlatives in the Imbricate Zone and the Eastern Hinterland are likely to be Caledonian in age.

- The Caledonian kinematic framework is one of sinistral transpression, involving a complex interaction between strike-slip movements associated with a major sinistral shear zone in the east of the region and generally NW-directed oblique thrusting and folding further to the west.

- There is no field evidence for any significant orogenic activity between the deposition of the middle Proterozoic Trekant Series and the upper Proterozoic lower Cambrian(?) Zebra Series. This is in marked contrast with areas further to the south where widespread 'Grenville' (c. $1000 \mathrm{Ma}$ ) activity has been inferred. In this respect Dronning Louise Land has greater affinities with more northerly parts of the Caledonian belt in North-East Greenland, where Jepsen \& Kalsbeek (1985) found no evidence for the existence of the supposed mid- to upper Proterozoic 'Carolinidian' orogeny.

\section{References}

Collinson, J. D. 1980: Stratigraphy of the Independence Fjord Group (Proterozoic) of eastern North Greenland. Rapp. Grønlands geol. Unders. 99, 7-23.

Haller, J. 1956: Die Structurelemente ostgrönlands zwischen $74^{\circ}$ und $78^{\circ}$ N. Meddr Grønland 154(2), $27 \mathrm{pp}$.

Haller, J. 1970: Tectonic map of East Greenland (1:500,000). An account of tectonism, plutonism, and volcanism in East Greenland. Meddr Grønland 171(5), 286 pp.

Haller, J. 1971: Geology of the East Greenland Caledonides, 413 pp. London: Interscience.
Haller, J. 1983: Geological map of northeast Greenland $75^{\circ}-$ $82^{\circ}$ N. lat. 1:1,000,000. Meddr Grønland 200(5), 22 pp.

Henriksen, N. \& Higgins, A. K. 1976: East Greenland Caledonian fold belt. In Escher, A. \& Watt, W. S. (edit.) Geology of Greenland, 182-246. Copenhagen: Geol. Surv. Greenland.

Holdsworth, R. E. 1988: The stereographic analysis of facing. J. Struct. Geol. 10, 219-223.

Hurst, J. M., Jepsen, H. F., Kalsbeek, F., McKerrow, W. S. \& Peel, J. S. 1985: The geology of the northern extremity of the East Greenland Caledonides. In Gee, D. G. \& Sturt, B. A. (edit.) The Caledonide Orogen: Scandinavia and related areas, 1047-1063. London: Wiley \& Sons.

Jepsen, H. F. \& Kalsbeek, F. 1979: Igneous rocks in the Proterozoic platform of eastern North Greenland. Rapp. Grønlands geol. Unders. 88, 11-14.

Jepsen, H. F. \& Kalsbeek, F. 1985: Evidence for non-existence of a Carolinidian fold belt in eastern North Greenland. In Gee, D. G. \& Sturt, B. A. (edit.) The Caledonide Orogen: Scandinavia and related areas, 1071-1076. London: Wiley \& Sons.

Koch, J. P. \& Wegener, A. 1930: Wissenschaftliche Ergebnisse der dänischen Expedition nach Dronning Louise Land und quer über das Inlandeis von Nordöstgrönland 1912-13 unter Leitung von J. P. Koch. Meddr Grønland 75, 676 pp.

Koch, L. 1929: The geology of East Greenland. Meddr Grønland 143(1), $204 \mathrm{pp}$.

Peacock, J. D. 1956a: The geology of Dronning Louise Land, N.E. Greenland. Meddr Grønland 137(7), 38 pp.

Peacock, J. D. 1956b: Geology of the Britannia S $\varnothing$ area, Dronning Louise Land. In Hamilton, R. A. et al. (edit.) British North Greenland Expedition 1952-54. Scientific results. Geogr. J. 122, 210-213.

Peacock, J. D. 1958: Some investigations into the geology and petrography of Dronning Louise Land, N.E. Greenland. Meddr Grønland 157(4), 139 pp. 